\title{
HUBUNGAN MOTIVASI BELAJAR DAN KONSEP DIRI SISWA DENGAN KETERAMPILAN BERPIKIR TINGKAT TINGGI PADA MATERI STOIKIOMETRI UNTUK SISWA KELAS X MIPA SMA NEGERI 4 SURAKARTA TAHUN PELAJARAN 2017/2018
}

\author{
Desita Kamila Ulfa* Sri Yamtinah, dan Budi Utami \\ Program Studi Pendidikan Kimia, FKIP,Universitas Sebelas Maret, Surakarta, Indonesia \\ * Keperluan korespondensi, tel/fax : +6282-242691682, email: desitamila12@gmail.com
}

\begin{abstract}
ABSTRAK
Penelitian ini bertujuan mengetahui : (1) hubungan motivasi belajar dengan keterampilan berpikir tingkat tinggi, (2) hubungan konsep diri dengan keterampilan berpikir tingkat tinggi, dan (3) hubungan motivasi belajar dan konsep diri dengan keterampilan berpikir tingkat tinggi materi stoikiometri kelas X MIPA SMA Negeri 4 Surakarta. Penelitian dilakukan dengan metode kuantitatif deskriptif korelasional. Teknik pengambilan sampel menggunakan teknik cluster random sampling dengan dipilih kelas X MIPA 1, X MIPA 2, dan X MIPA 5 sebagai sampel serta kelas $X$ MIPA 4 sebagai kelas uji coba instrumen. Data penelitian diperoleh melalui pengisian angket dan tes soal pilihan ganda. Hasil penelitian menunjukkan : (1) ada hubungan motivasi belajar dengan keterampilan berpikir tingkat tinggi dengan koefisien korelasi sebesar 0,652; (2) ada hubungan konsep diri dengan keterampilan berpikir tingkat tinggi dengan koefisien korelasi sebesar 0,522; dan (3) ada hubungan motivasi belajar dan konsep diri dengan keterampilan berpikir tingkat tinggi dengan koefisien korelasi sebesar 0,699 . Koefisien korelasi bernilai positif dengan signifikansi $0,000(\rho<0,05)$ sehingga hubungan positif dan signifikan. Hasil uji regresi diperoleh persamaan : $Y=-44,769+0,680 X_{1}+0,523 X_{2}$ dan nilai koefisien determinasi sebesar 0,489 atau $48,9 \%$.
\end{abstract}

Kata Kunci : Motivasi belajar, konsep diri, keterampilan berpikir tingkat tinggi

\section{PENDAHULUAN}

Pembelajaran kimia merupakan salah satu mata pelajaran wajib di Sekolah Menengah Atas (SMA). Kimia termasuk salah satu cabang ilmu dalam sains yang berkaitan erat dengan kehidupan sehari-hari berdasarkan pada penyajian fakta bukan hanya konsep termasuk perubahan yang menyertainya terkait dengan reaksi kimia [1]. Konsep kimia yang sangat dekat dengan kehidupan membuat siswa untuk memperoleh ilmu pengetahuan dan keterampilan dalam mempelajarinya. Stoikiometri merupakan salah satu materi dalam kimia. Materi stoikiometri sangat membutuhkan pemahaman konsep kimia dan kemampuan numerik yang tinggi [2]. Hal tersebut sesuai dengan karakteristik isi materi pada bab tersebut yang berupa konsep - konsep tentang hukum dasar kimia dan rumus rumus yang menyertai, baik rumus senyawa maupun rumus perhitungan. Berdasarkan peraturan menteri pendidikan dan kebudayaan nomor 69 Tahun 2013 tentang kerangka dasar dan struktur kurikulum Sekolah Menengah Atas (SMA), kurikulum 2013 merupakan kurikulum yang saat ini berlaku dalam sistem pendidikan di Indonesia mulai tahun ajaran 2013/2014 [3]. Selain itu, kurikulum 2013 sangat penting diterapkan dalam pembelajaran kimia. Kurikulum 2013 memiliki karakteristik yang mampu untuk mendukung siswa untuk mengembangkan kemampuannya dalam hal penalaran dan berpikir kritis terhadap suatu permasalahan. Kurikulum 2013 dengan pendekatan 
saintifik akan membuat siswa untuk bersifat terbuka terhadap pemikirannya dan mampu untuk berpikir kreatif dan aktif sehingga pembelajaran dapat berjalan efektif serta akan meningkatkan keterampilan berpikir tingkat tinggi. Keterampilan berpikir tingkat tinggi menjadi fokus yang sangat penting dalam kurikulum 2013. Menurut Anderson \& Krathwohl (2001), keterampilan berpikir tingkat tinggi dapat diperoleh melalui aktivitas mengamati, menanya, mencoba, menalar, menyaji dan mencipta [4]. Semua aktivitas tersebut sesuai dengan langkah-langkah pembelajaran dengan pendekatan saintifik. Sehingga pada penerapan kurikulum 2013 dengan pendekatan saintifik akan mampu melaksanakan pembelajaran secara efektif dan menghasilkan siswa yang produktif, kreatif, inovatif dan afektif serta mampu berkontribusi pada kehidupan bermasyarakat, berbangsa, bernegara dan peradaban dunia sesuai tujuannya. SMA Negeri 4 Surakarta yang merupakan salah satu sekolah favorit di Surakarta yang telah menerapkan kurikulum 2013 dengan pendekatan saintifik pada proses pembelajarannya khususnya pembelajaran kimia. Keberhasilan penerapan kurikulum 2013 dengan mengembangkan keterampilan berpikir tingkat tinggi siswa di SMA Negeri 4 Surakarta telah ditunjukkan dengan banyaknya prestasi yang diraih oleh siswa, baik prestasi akademik maupun non akademik. Berdasarkan data puspendik kemdikbud pada beberapa SMA se-Surakarta menunjukkan bahwa SMA Negeri 4 Surakarta menduduki peringkat 3 untuk tingkat SMA/SMK se-Surakarta dengan rata-rata UNBK tahun 2017 sekitar 79,06 [5].

Proses pembelajaran dengan pendekatan saintifik berdasarkan kurikulum 2013 dalam mencapai keterampilan berpikir tingkat tinggi dipengaruhi oleh beberapa hal diantaranya motivasi belajar dan konsep diri. Motivasi merupakan proses pengerahan dan penguatan motif untuk diaktualisasi dalam perbuatan nyata. Motivasi mencakup konsep - konsep, seperti kebutuhan berprestasi, kebutuhan berafiliasi, kebiasaan dan keingintahuan seseorang terhadap sesuatu [6]. Motivasi yang dimiliki siswa akan membuat mereka tergerak untuk bisa melakukan sesuatu yang men-dukung dalam mencapai tujuan pem-belajaran. Penerapan pembelajaran dengan pendekatan saintifik berdasarkan kurikulum 2013 yang berpusat pada siswa akan membuat siswa menjadi aktif dan kreatif, selalu ditantang untuk memiliki daya kritis, mampu menganalisis serta mampu memecahkan masalahnya sendiri. Hal tersebut akan membutuhkan adanya motivasi belajar siswa yang berperan dalam proses pembelajaran agar dapat berjalan efektif karena melibatkan peran guru dan siswa secara langsung. Motivasi yang rendah akan menjadi penghalang dalam pembelajaran dan menyebabkan kemunduran dalam standar pendidikan [7].

Pembentukan konsep diri juga termasuk dalam salah satu prinsip pembelajaran dengan pendekatan saintifik. Konsep diri meliputi penilaian terhadap dirinya, lebih percaya diri, semangat yang tinggi, optimis, mudah menerima pelajaran dan merasa mampu mencapai prestasi belajar yang baik. Konsep diri memiliki peran sangat penting sebagai faktor yang berpengaruh dalam perilaku dan berbagai hasil emosional serta kognitif (keinginan, prestasi akademik, kebahagiaan, keputusasaan, kepercayaan diri dan lain - lain). Selain itu, konsep diri juga dianggap sebagai faktor penengah untuk mencapai hasil pembelajaran yang diinginkan, psikologi dan tingkah laku [8]. Berkaitan dengan salah satu tujuan pembelajaran pada kurikulum 2013 yang hendak dicapai yaitu meningkatkan perkembangan intelektual, khususnya keterampilan berpikir tingkat tinggi melalui pengukuran kemampuan mental siswa. Jadi konsep diri memiliki kaitan dengan keterampilan berpikir tingkat tinggi siswa. Sebaliknya jika konsep diri yang dimiliki siswa rendah maka siswa tidak akan mampu untuk mengembangkan keterampilan berpikir tingkat tinggi yang dimilikinya. Karena rendahnya konsep diri, siswa kurang berani untuk mengeksplore dirinya dan 
membuka pikirannya dalam menentukan keputusan-keputusan jika menghadapi masalah baru.

Berdasarkan penjelasan di atas, peneliti ingin membuktikan adanya hubungan positif antara motivasi belajar dan konsep diri dengan keterampilan berpikir tingkat tinggi, maka perlu dilakukan penelitian tentang "Hubungan Motivasi Belajar dan Konsep Diri Terhadap Keterampilan Berpikir Tingkat Tinggi Siswa pada Pokok Materi Stoikiometri Kelas X MIPA SMA Negeri 4 Surakarta Tahun Pelajaran 2017/2018"

\section{METODE PENELITIAN}

Penelitian ini merupakan penelitian deskriptif kuantitatif dengan pendekatan korelasional. penelitian deskriptif dengan pendekatan korelasional merupakan suatu metode penelitian yang dilakukan dengan tujuan utama membuat gambaran atau deskripsi tentang suatu keadaan yang bersifat faktual secara objektif, kemudian melakukan analisis terhadap pengaruh antara faktor efek (variabel terikat) dengan faktor risiko (variabel bebas) berdasarkan koefisien korelasi [9]. Metode deskriptif dengan pendekatan korelasional dalam penelitian ini bertujuan untuk mengetahui ada tidaknya hubungan positif antara motivasi belajar dan konsep diri dengan keterampilan berpikir tingkat tinggi siswa. Subjek penelitian ini adalah kelas X MIPA SMA Negeri 4 Surakarta Tahun Ajaran 2017/2018. Teknik pengambilan sampel adalah cluster random sampling karena populasi terbagi dalam kelas - kelas [10]. Kelas X MIPA 1, X MIPA 2, dan X MIPA 5 dipilih sebagai kelas sampel dan $X$ MIPA 4 sebagai kelas uji coba karena dianggap telah mampu untuk mewakili populasi.

Teknik pengumpulan data dilakukan dengan teknik tes. Data penelitian diperoleh dari skor angket yang masing masing berjumlah 25 pernyataan untuk mengukur motivasi belajar dan konsep diri, serta skor soal pilihan ganda yang berjumlah 15 soal untuk mengukur keterampilan berpikir tingkat tinggi siswa. Teknik analisis instrumen angket motivasi belajar dan konsep diri dilakukan dengan menggunakan uji validitas dan reliabilitas. Sedangkan analisis soal dianalisis menggunakan uji validitas, uji reliabilitas, tingkat kesukaran soal, dan daya pembeda soal. Berdasarkan uji validitas instrumen angket motivasi belajar, konsep diri dan soal keterampilan berpikir tingkat tinggi yang dilakukan dengan menggunakan formula Gregory diperoleh hasil validitas isi masing-masing sebesar 1,00. Uji reliabilitas angket motivasi belajar dan konsep diri menggunakan formula statistika Alfa Cronbach menghasilkan nilai reliabilitas masing-masing sebesar 0,873 dan 0,699. Sedangkan uji reliabilitas soal keterampilan berpikir tingkat tinggi menggunakan ITEMAN diperoleh nilai sebesar 0,739 . Hasil uji tingkat kesukaran menunjukkan soal memiliki klasifikasi tingkat kesukaran sedang sebanyak 7 soal dan sukar sebanyak 8 soal. Hasil uji daya pembeda soal menunjukkan soal dalam kriteria cukup sebanyak 6 soal, baik sebanyak 8 soal, dan baik sekali sebanyak 1 soal. Hasil tersebut menunjukkan bahwa instrumen layak untuk digunakan sebagai instrumen untuk penelitian.

\section{HASIL DAN PEMBAHASAN}

Berdasarkan hasil uji statistik skor angket motivasi belajar dan konsep diri siswa diperoleh hasil bahwa siswa kelas $X$ MIPA SMA Negeri 4 Surakarta mayoritas memiliki motivasi belajar dalam kategori baik dengan presentase sebesar $72 \%$. Konsep diri yang dimiliki siswa mayoritas berada pada kategori baik dengan presentase sebesar $81 \%$. Sedangkan hasil uji statistik nilai soal keterampilan berpikir tingkat tinggi siswa menunjukkan bahwa mayoritas siswa berada pada kategori cukup dengan presentase $66 \%$.

Hasil analisis menggunakan teknik analisis korelasi dan regresi ganda untuk menguji hipotesis yang ada. Uji hipotesis pertama untuk mengetahui ada tidaknya hubungan antara motivasi belajar $\left(\mathrm{X}_{1}\right)$ dengan keterampilan berpikir tingkat tinggi $(\mathrm{Y})$ jika konsep diri $\left(\mathrm{X}_{2}\right)$ dianggap konstan. Uji hipotesis kedua untuk mengetahui ada tidaknya hubungan 
antara konsep diri $\left(\mathrm{X}_{2}\right)$ dengan keterampilan berpikir tingkat tinggi $(Y)$ jika motivasi belajar $\left(\mathrm{X}_{1}\right)$ dianggap tetap. Hipotesis ketiga mengetahui ada tidaknya hubungan antara motivasi belajar $\left(X_{1}\right)$ dan konsep diri $\left(X_{2}\right)$ dengan keterampilan berpikir tingkat tinggi.

Berdasarkan hasil uji hipotesis pertama menunjukkan adanya hubungan positif dan signifikan antara motivasi belajar $\left(X_{1}\right)$ dengan keterampilan berpikir tingkat tinggi (Y). Hal tersebut dibuktikan dengan nilai koefisien korelasi sebesar 0,625 dengan nilai positif dan nilai signifikansi sebesar 0,000 $(\rho<0,05)$ yang berarti bahwa $\mathrm{H}_{0}$ ditolak. Koefisien korelasi yang bernilai positif menunjukkan bahwa semakin tinggi motivasi belajar siswa maka semakin tinggi pula keterampilan berpikir tingkat tinggi siswa. Sebaliknya, semakin rendah motivasi belajar siswa maka semakin rendah keterampilan berpikir tingkat tinggi yang dimilikinya. Berdasarkan nilai koefisien korelasi tersebut maka tingkat keeratan hubungan motivasi belajar dengan keterampilan tingkat tinggi yang dihasilkan berada pada tingkat hubungan cukup/sedang. Hasil penelitian ini sesuai dengan penelitian Waminton (2016) yang menunjukkan ada hubungan positif dan signifikan antara motivasi belajar dengan kemampuan komunikasi matematika yang memiliki nilai koefisien korelasi sebesar 0,287 [11]. Penelitian Sartika (2015) juga menunjukkan hasil yang sama yaitu terdapat adanya hubungan positif dan signifikan antara motivasi belajar dengan hasil belajar siswa dengan nilai koefisien korelasi sebesar 0,330 [12]. Penelitian Peipei Li \& Guirong Pan (2009) juga menjelaskan adanya pengaruh faktor motivasi terhadap prestasi [13]. Hal tersebut menunjukkan bahwa motivasi belajar yang tinggi akan mempengaruhi tingkah laku dan perbuatan siswa dalam pembelajaran sehingga siswa mampu membangun keterampilan siswa untuk memiliki prestasi yang tinggi.

Hasil uji hipotesis kedua menunjukkan adanya hubungan positif dan signifikan antara konsep diri siswa $\left(X_{2}\right)$ dengan keterampilan berpikir tingkat tinggi (Y). Hal tersebut dibuktikan dengan nilai koefisien korelasi sebesar 0,522 dengan nilai positif dan nilai signifikansi sebesar 0,000 $(\rho<0,05)$ yang berarti bahwa $\mathrm{H}_{0}$ ditolak. Koefisien korelasi yang bernilai positif menunjukkan bahwa semakin tinggi konsep diri siswa maka semakin tinggi pula keterampilan berpikir tingkat tinggi siswa. Sebaliknya, semakin rendah konsep diri siswa maka semakin rendah keterampilan berpikir tingkat tinggi yang dimilikinya. Berdasarkan nilai koefisien korelasi tersebut maka tingkat keeratan hubungan konsep diri dengan keterampilan tingkat tinggi yang dihasilkan berada pada tingkat hubungan cukup/sedang. Beberapa penelitian menunjukkan pentingnya konsep diri positif terhadap prestasi akademik. Penelitian Mcinerney (2012), menunjukkan adanya hubungan resiprosikal antara konsep diri dengan prestasi siswa [14]. Penelitian Marsh (2010) juga menunjuk-kan bahwa adanya peningkatan konsep diri akademik mempe-ngaruhi kenaikan prestasi akademik dan hasil pendidikan lain yang diinginkan [15]. Penelitian Efendi (2014) menyebutkan bahwa konsep diri memiliki sumbangan $21,16 \%$ dalam mempengaruhi prestasi akademik. Semakin positif konsep diri yang dimiliki seseorang maka semakin meningkat prestasi belajarnya [16]. Penelitian Liauwrencia (2014) menunjukkan hubungan signifikan dalam taraf sedang antara konsep diri dengan prestasi akademik dengan nilai koefisien korelasi sebesar 0,381 [17]. Konsep diri yang baik akan mempengaruhi siswa dalam memunculkan persepsi-persepsi yang baik terhadap dirinya saat sedang melakukan interaksi dengan orang lain. Hal tersebut penting dalam pembelajaran karena dengan adanya persepsi positif, siswa akan menjadi lebih percaya diri untuk mengembangkan kemampuan yang dimilikinya.

Berdasarkan hasil uji hipotesis pertama menunjukkan adanya hubungan positif dan signifikan antara motivasi belajar $\left(\mathrm{X}_{1}\right)$ dan konsep diri $\left(\mathrm{X}_{2}\right)$ dengan keterampilan berpikir tingkat tinggi $(\mathrm{Y})$. Hal tersebut dibuktikan dengan nilai koefisien korelasi sebesar 0,699 dengan nilai positif dan nilai signifikansi sebesar 
$0,000(\rho<0,05)$ yang berarti bahwa $\mathrm{H}_{0}$ ditolak. Berdasarkan nilai koefisien korelasi tersebut maka tingkat keeratan hubungan motivasi belajar dan konsep diri dengan keterampilan tingkat tinggi yang dihasilkan berada pada tingkat hubungan cukup/sedang. Hasil penelitian ini sejalan dengan penelitian Warminton (2016) yang menunjukkan ada hubungan positif yang signifikan antara motivasi belajar dan konsep diri dengan kemampuan komunikasi matematika yang memiliki nilai koefisien korelasi sebesar 0,406 [11]. Penelitian Efendi (2014) menunjukan bahwa ada hubungan positif yang signifikan antara konsep diri dan motivasi belajar dengan prestasi akademik mahasiswa dengan koefisien korelasi sebesar 0,566 [16]. Selain itu Penelitian Prayoonsri (2015) menunjuk-kan bahwa karakteristik psikologi memiliki hubungan positif dan signifikan dengan keterampilan berpikir tingkat tinggi yang memiliki nilai koefisien korelasi sebesar 0,762 [18]. Karakteristik psikologi dapat dipengaruhi diantaranya oleh motivasi dan konsep diri. Jadi motivasi belajar dan konsep diri yang dimiliki siswa akan mempengaruhi keterampilan berpikir tingkat tinggi yang dimiliki.

Berdasarkan hasil uji regresi berganda diperoleh persamaan :

$Y=-44,769+0,680 X_{1}+0,523 X_{2}$

Keterangan :

$\mathrm{Y}=$ Keterampilan berpikir tingkat tinggi

$\mathrm{X}_{1}=$ Motivasi Belajar

$\mathrm{X}_{2}=$ Konsep Diri

Hasil uji regresi linier berganda menunjukkan pengaruh motivasi belajar terhadap keterampilan berpikir tingkat tinggi siswa sebesar 0,680 dengan nilai positif yang berarti jika motivasi belajar siswa meningkat 1 poin maka keterampilan berpikir tingkat tinggi siswa akan meningkat sebesar 0,680 . Sedangkan pengaruh konsep diri siswa terhadap keterampilan berpikir tingkat tinggi siswa sebesar 0,523 dengan nilai positif berarti jika konsep diri siswa meningkat 1 poin maka keterampilan berpikir tingkat tinggi siswa akan meningkat sebesar 0,523. Hasil tersebut menunjukkan bahwa variabel motivasi belajar memiliki pengaruh lebih besar dibandingkan dengan variabel konsep diri.

Berdasarkan perhitungan, nilai keterampilan berpikir tingkat tinggi $(Y)$ akan diperoleh saat motivasi belajar $\left(X_{1}\right)$ dan konsep diri siswa $\left(\mathrm{X}_{2}\right)$ berada pada nilai maksimal. Hal tersebut ditunjukkan pada perhitungan sebagai berikut :

$Y=-44,769+0,680 X_{1}+0,523 X_{2}$

$Y=-44,769+0,680(100)+0,523(100)$

$Y=-44,769+68+52,3$

$Y=75,531$

Pada perhitungan di atas, jika nilai $X_{1}$ dan $X_{2}$ memiliki nilai maksimal $\left(X_{1}\right.$ dan $X_{2}=100$ ), maka diperoleh nilai $Y$ sebesar 75,53. Hal tersebut membuktikan bahwa nilai motivasi belajar dan konsep diri secara bersama - sama mempengaruhi nilai keterampilan berpikir tingkat tinggi siswa. Semakin tinggi nilai motivasi belajar dan konsep diri yang diperoleh siswa maka semakin tinggi pula nilai keterampilan berpikir tingkat tingginya. Sebaliknya, semakin rendah nilai motivasi belajar dan konsep diri yang diperoleh siswa maka semakin rendah pula nilai keterampilan berpikir tingkat tingginya. Koefisien determinasi $\left(R^{2}\right)$ yang dihasilkan menunjukkan variabel motivasi belajar $\left(X_{1}\right)$ dengan dan variabel konsep diri $\left(X_{2}\right)$ secara bersama-sama memiliki hubungan dengan variabel keterampilan berpikir tingkat tinggi siswa (Y) sebesar 0,489 yang berarti bahwa keterampilan berpikir tingkat tinggi siswa dipengaruhi 48,9\% motivasi belajar dan konsep diri. Sedangkan sisanya dipengaruhi oleh faktor lain yang tidak diteliti.

\section{KESIMPULAN}

Berdasarkan hasil penelitian dapat disimpulkan bahwa siswa kelas X MIPA SMA Negeri 4 Surakarta memiliiki motivasi belajar dan konsep diri yang berpengaruh positif terhadap keterampilan berpikir tingkat tinggi siswa dengan nilai koefisien korelasi masing-masing sebesar 0,625 dan 0,522. Sedangkan pengaruh motivasi belajar dan konsep diri terhadap keterampilan berpikir tingkat tinggi memiliki nilai koefisien korelasi ganda sebesar 0,699. Hasil uji regresi ganda diperoleh persamaan : $\mathrm{Y}=$ 
- 44,769+0,680 X $1+0,523 X_{2}$ dan nilai koefisien determinasi sebesar 0,489 atau $48,9 \%$.

\section{UCAPAN TERIMA KASIH}

Penulis mengucapkan terima kasih kepada semua pihak yang telah membantu dan mendukung terselesainya penelitian ini. Terutama kepada Drs. M. Thoyibun, S.H., M.M., selaku kepala sekolah SMA Negeri 4 Surakarta dan Dra. Wiwik Winarti, MM, M.Pd., selaku guru kimia kelas X MIPA SMA Negeri 4 Surakarta yang telah memberikan ijin untuk melakukan penelitian dan menggunakan kelas yang diampu untuk penambilan data penelitian. Serta siswa -siswi kelas X MIPA SMA Negeri 4 Surakarta yang telah membantu dalam penelitian ini.

\section{DAFTAR RUJUKAN}

[1] Brady, J. E., 1994, Kimia Universitas: Asas dan Struktur, Erlangga, Jakarta.

[2] Putri, G. Y. P., Redjeki, T., dan Nurhayati, N. D., 2016, J. Pendidik. Kim., 5(4), 51-59.

[3] Kemendikbud, 2013, Permendikbud No. 69 Tahun 2013 Tentang Kerangka Dasar dan Struktur Kurikulum Sekolah Menengah Atas/Madrasah Aliyah.

[4] Anderson dan Krathwohl, 2001, A Taxonomy for Learning, Teaching, and Assesing (A revision of Bloom's Taxonomy of Educational Objectives, David McKay Company, New York.

[5] Kemendikbud, 2017, Rekap Hasil Ujian Nasional (UN) Tingkat Sekolah, diperoleh pada 25 Desember 2017, dari http://puspendik.kemdikbud.go.id/h asil-un/.
[6] Uno, H. B., 2006, Teori Motivasi dan Pengukurannya, PT Bumi Aksara, Jakarta .

[7] Lawrence, A. S. A. dan Vimala, A., 2013, Conflux J. Educ., 1(1), 141205.

[8] Craven, R., Marsh, H., dan Burnett, P., 2003, Int. Adv. Self Res., 36(5), 91-126.

[9] Danim, S., 2002, Menjadi Peneliti Kualitatif, Pustaka Setia, Bandung.

[10] Creswell, J. W., 2009, Research Design: Qualitative, Quantitative, and Mixed Methods Approaches, SAGE Publication, United State of Amerika.

[11] Rajagukguk, W., 2016, Intenational Educ. Stud., 9(4), 155-164.

[12] Sartika, R., Agustina, dan Basri, I., 2015, J. Bahasa, Sastra, dan Pembelajaran, 3(1), 12-26.

[13] Li, P. dan Pan G., 2009, English Lang. Teach., 2(1), 123-128.

[14] Mcinerney, D. M., Cheng, R. W., Mo M., dan Mok, C., 2012, J. Adv. Academics, 23(3), 249-269.

[15] Marsh, H. W. dan Martin, A. J., 2011, J. Educ. Psychol., 81, 59-77.

[16] Efendi, A. L., Rosra, M., dan Yusmansyah, 2014, J. Bimbing. Konseling, 3(1), 154-167.

[17] Liauwrencia, P. F. dan Putra, D., 2014, J. NOETIC Psychol., 4(1), 62-80.

[18] Budsankom P., Sawangboon T., dan Damrongpanit S., 2015, Acad. Journals, 10(19), 2639-2652. 